\title{
Academic Library Instruction
}

\begin{abstract}
Thirty academic libraries in Poland that give students instruction in library use were polled as to their experiences and observations. Many of their concerns proved common to such programs in other parts of the world and seem to bid for attention on an international level.
\end{abstract}

\section{M} ANY ACADEMIC LIBRARIANS from different countries, in discussing the instructive aspects of their work, agree that perhaps these are among the most difficult of their duties. This is as true in teaching first-year students as in teaching graduate students. Awareness of the problems of library and bibliographical instruction has so increased, especially since the second World War, that courses in library usage have even been inserted into many college curricula.

The world library press has published a large number of articles on this subject, and in some countries more than in others energetic librarians have directed attention to the problem. ${ }^{1}$ The published results of their inquiries have been so varied that it is difficult to find in them any general conclusion except that library instruction prospers most when there is collaboration between the administration of the college and the library. It is important that adequate qualified staff members be available as instructors. Although many leading libraries do not

Lloyd W. Griffin and J. A. Clarke, "Orientation and Instruction of the Graduate Student by University Libraries," CRL, XIX (November 1958), 451-54; E. J. Josey, "The Role of the College Library Staff in Instruction in the Use of the Library," CRL, XXIII (November 1962), 492-98; P. Havard-Williams, "The Student and the University Library," Library Association Record, LX (September 1958), 269-72 ; "Journées d'etude des Bibliothèques de France," Bulletin des Bibliothèques de France, IV (January 1959), 21-51; Maria Wójeik, "Przysposobienie Biblioteczne Studentów Szkól Wyzszych," Przeglad Biblioteczny, XXIX (April 1961), 163-77.

Maria Wójicik is head of the Central Catalog in the Jagiellonian University Library in Cracow, Poland. instruct students, those which have done so consider such a cause an important achievement.

In Poland the sporadic offering of library instruction to college students began between the two wars. In the period 1952-1954 the Ministry of High Schools commissioned all of its college and university libraries to give instruction in library usage to all first-year students. In January 1960 the main library of Agricultural College in Cracow studied the library instruction being given in the thirty-one libraries then under the direction of the Ministry of High Schools.

Thirty libraries replied to an inquiry sent out by the college. Their replies indicated that in the colleges of economics an average of five to six hours of library instruction was being given; other colleges averaged between two and three hours. Widest variation was in the agricultural colleges, which offered from one to twelve hours, with an average of two. Among major problems being experienced with the programs were the number of hours allowed to it, the organization and preparation of themes by individuals and groups, exercises with the catalogs, etc. It also appeared to be important whether or not the individual college considered the program obligatory for the students and required a report on their accomplishments at the end of the year.

Work with first-year students is generally considered more important in Poland than work with graduate students, since the latter are usually more careful 
and appreciative of the advantages of bibliographic instruction. Yet it is worth noting that some-although not manyPolish libraries do conduct instructional exercises with graduate students in addition to their work with first-year students. The college libraries seem to be more active in this regard than do those in universities, since none of the university libraries reported working with graduates. Several agricultural and economics college libraries, however, were carrying on such exercises or had planned them for the immediate future. During the 600-year jubilee of the Jagiellonian University, for example, the size of the library staff was increased and an enlarged organizational structure was approved, allowing considerable improvement in the library instructional program, both to undergraduates and to graduates.

It should be noted that college faculty members more frequently speak in support of undergraduate than of graduate library instruction. This may result from the fact that the entire library practice of undergraduates takes place under the eye of librarians, whereas the bibliographic work of graduate students often receives closer attention from faculty members. Some librarians have expressed the opinion that the training of first-year students should be left to the care of librarians but that the training of graduate students ought to be the business of the faculty. The division of these duties between librarians and faculty members could be fixed by a joint conference of representatives of both groups.

Although as a rule questionnaires are not welcomed by overworked librarians, this one in Poland seemed to elicit the goodwill of its respondents. Replies were generally full of particulars and showed great interest in the subject, and, even before publication of the results, queries were received concerning them. This interest is probably to be expected since it is a newer branch of librarianship than the basic work of acquisition, cataloging, and circulation. It should also be noted that it requires of the librarian pedagogical talents and skills to a degree not formerly necessary.

Part of a good library instructional program should require close contact between librarians and the persons in charge of library schools themselves, but the two must not be confused. The work of the library schools is instruction in internal library routines, services, and administration; it is the professional education of librarians and is performed from another point of view than giving library instruction to general students. This point does not need emphasis here, but it is useful to note that in 1959 a conference was held in Poland to consider the circumstances and needs of the library schools. At this conference-in which college and university faculty participated-librarians presented a motion that librarians should give bibliographic instruction to graduates. Since the motion was not in order, no action was taken although its introduction was noted in the minutes of the conference.

It is important to observe that in the past much of the work of giving library instruction to students has been done by librarians without the help of college and university administrators, and that the burden it places on other aspects of library work is frequently excessive. Additional work on the subject is still needed. From observing developments in library instruction over many years-not only in Poland but in the rest of the world as well-one concludes that the situation is mature for recapitulation and re-examination on an international scale. It would be helpful for further work on the subject to be coordinated under such an organization as IFLA. All over the world there is discussion concerning the reform of higher education and its practical simplification. Much help would seem to result from the realization of a general international program of library instruction for undergraduates and bibliographic instruction for graduates. 